\title{
The Effectiveness of Using Aloe Vera Facial Soap and Aloe Gel on the Degree of Acne Vulgaris in Students of SMA Negeri 2 Bayang
}

\author{
Putri Bunga Anggreno Setiawan ${ }^{1}$, Ade Teti Vani ${ }^{2}$, Budi Yulhasfi Febrianto ${ }^{3}$, Vina Tri Septiana ${ }^{4}$ \\ ${ }^{1}$ Fakultas Kedokteran Universitas Baiturrahmah, Padang,Indonesia \\ ${ }^{2}$ Bagian Histologi Fakultas Kedokteran Universitas Baiturrahmah, Padang, Indonesia \\ ${ }^{3}$ Bagian Bedah Fakultas Kedokteran Universitas Baiturrahmah, Padang, Indonesia \\ ${ }^{4}$ Bagian Radiologi Fakultas Kedokteran Universitas Baiturrahmah, Padang, Indonesia
}

ARTICLE INFO

Keywords:

Aloe vera gel, facial wash

aloe vera, Acne vulgaris.
Email :

Putribunga12@gmail.com

Adeteti09@gmail.com

Febriantobudi19@gmail.com Vinatri87@gmail.com

\begin{abstract}
Acne vulgaris is an inflammatory skin condition caused by polysebaceous units that occurs in adolescents and young adults characterized by comedones, papules, pustules, and nodules. Records of the Indonesian cosmetic dermatology study group showed $60 \%$ of acne vulgaris sufferers in 2006 and $80 \%$ in 2007 . Accur acne vulgaris 80 to $100 \%$ in young adults, namely 14-17 years in women, and 16-19 years in men. One of the plants that are useful as facial wash aloe vera. Aloe vera as an ingredient in making soap, is not only able to kill bacteria, but also can smooth the skin.Objective: to find the effectiveness application aloe vera facial wash and aloe vera gel between the degree of acne vulgaris in student at SMA Negeri 2 Bayang. Methods: The scope of this research includes pharmacology and dermatology. Located of this research will be at SMA Negeri 2 Bayang Pesisir Selatan. The time of the research was carried out in April 2021. This type of research is a form of experiment pre-test and post-test control group design. The target population in this research were students of SMA Negeri 2 Bayang Pesisir Selatan who suffered from acne vulgaris on the facial skin. Data analysis using paired sample t test and independent $t$ test. Result: most students are 17 years old 8 people (40\%), the most gender are women as many as 18 people $(90 \%)$, there is a effectiveness between the use of aloe vera facial wash and aloe vera gel with the degree of acne vulgaris in students at SMA Negeri 2 Bayang. ( $\mathrm{P}=$ 0.000 ) and there is a effectiveness between the use of aloe vera facial wash and the degree of acne vulgaris in students at SMA Negeri 2 Bayang. $(\mathrm{P}=0.040)$. Conclusion: there is a the effectiveness application aloe vera facial wash and aloe vera gel between the degree of acne vulgaris in students at SMA Negeri 2 Bayang.
\end{abstract}

Copyright (C) 2020 Eduhot Journal.All rights reserved is Licensed under a Creative Commons Attribution- NonCommercial 4.0 International License (CC BY-NC

4.0)

\section{INTRODUCTION}

Acne vulgaris is an inflammatory skin condition caused by polysebaceous units that occurs in adolescents and young adults characterized by comedones, papules, pustules, and nodules. 1 The distribution of acne depends on the density of pilosebaceous units, especially on the face, neck, chest, shoulders and back. Acne vulgaris can cause scars resulting in a lack of self-confidence, and can also lead to depression, therefore acne requires serious treatment.2

Records of the Indonesian cosmetic dermatology study group showed that there were $60 \%$ of acne vulgaris sufferers in 2006 and $80 \%$ in 2007. The incidence of acne vulgaris is 80 to $100 \%$ in young adults, namely 14-17 years in women, and 16-19 years in men. . In general, many teenagers have

The Effectiveness of Using Aloe Vera Facial Soap and Aloe Gel on the Degree of Acne Vulgaris in Students of SMA Negeri 2 Bayang Putri Bunga Anggreno Setiawan, Ade Teti Vani, Budi Yulhasfi 
problems with acne vulgaris because many teenagers have the wrong treatment and lack of knowledge about acne vulgaris.3.

Adolescents who have problems with acne vulgaris due to lack of knowledge about the factors that cause acne vulgaris (multifactorial), including genetic factors, racial factors, food factors, climate factors, skin type factors, hygiene factors, cosmetic use factors, stress factors, infection factors and occupational factors. Patients usually complain of a skin rash in the form of comedones, papules, pustules, nodules, and cysts that can be accompanied by itching, areas that often appear on the face, shoulders, upper part of the superior extremities, chest and back.

Facial hygiene can be done by using facial soap, facial soap is used at the first step in skin care. The soap is used to clean the face from exposure to dust, pollution, dirt, and reduce sebum on the face which can cause acne. 5 Keeping the face clean by washing the face regularly is done 2 times a day, not only using facial soap, it needs to be supported by using a facial skin moisturizer. like aloe vera gel.6

Aloe vera in Indonesia is widely known by the public as a traditional medicinal plant because it has many benefits and contains antioxidants consisting of monosaccharides, polysaccharides, essential and non-essential amino acids, enzymes, minerals, vitamins, anthraquinones, proteins, lignin, salicylate, saponins, sterols, tannins, magnesium lactate and prostaglandins. Substances that function as antibacterial are anthraquinones, saponins and tannins. Aloe vera is used to refresh, moisturize the skin and also has a protective effect against skin damage caused by radiation. Aloe vera also functions as an anti-aging agent that is useful for inhibiting the thinning process of the skin and preventing the loss of elastin fibers and increasing the water-soluble collagen content of the dermis.. ${ }^{7}$

Aloe vera contains many antioxidants that function as a source of raw materials for various products in the food, pharmaceutical and cosmetic industries. Aloe vera contains saponins that function as cleansing and hydrating properties antiseptic, Aloe vera also has accemanans that function as antivirus, anti-bacterial and anti-fungal. Utilizing Aloe vera as an ingredient for making soap, is not only able to kill bacteria, but can also smooth the skin. Lignin which functions to protect the skin to keep it moist and retain water in the skin, so that excessive evaporation does not occur. 8 The above explanation explains the content of Aloe vera that can affect the severity of acne vulgaris. Antiacne facial cleansing soap products that are circulating, but not yet Many studies have been conducted to determine the effectiveness of Aloe vera in inhibiting the growth of Propionilbacterium Acnes.

This study aims to determine the effectiveness of facial soaps and gels made from Aloe vera in inhibiting the growth of Propionibacterium acnes bacteria which is one of the factors causing acne vulgaris. Previous research conducted by Muhammad Silpi on the effect of aloe vera gel on acne vulgaris in class 2019 students of the Baiturrahmah University medical faculty, proved that there were significant differences in acne vulgaris before and after administration of aloe vera gel.9 Researchers are interested in developing previous research on aloe vera gel. against acne by adding facial soap, so this study aims to determine the effectiveness of aloe vera gel and aloe vera soap on the degree of acne vulgaris in students of SMA Negeri 2 Bayang.

Researchers are interested in conducting research in the southern coastal area because the southern coast is an area close to the beach and also the weather in this area is quite hot, the risk factor for acne vulgaris is food factors, one of which is high levels of iodine which can cause acne vulgaris, so researchers are interested in taking samples in this area. SMA Negeri 2 Bayang which is one of the high schools located on the south coast.8

Based on the description above, the formulation of the problem in this study is how the effect of aloe vera soap and aloe vera gel on the level of acne vulgaris in students at SMA Negeri 2 Bayang. This study aims to determine the effect of aloe vera facial soap and aloe vera gel on the level of acne vulgaris on students at SMA Negeri 2 Bayang.

\section{METHOD}

The scope of this research covers the fields of pharmacology and dermatology. The location of this research will be at SMA Negeri 2 Bayang Pesisir Selatan. The time of the study was carried out in April 2021. This type of research used an experimental study with a pre-test and post-test control group

The Effectiveness of Using Aloe Vera Facial Soap and Aloe Gel on the Degree of Acne Vulgaris in Students of SMA Negeri 2 Bayang Putri Bunga Anggreno Setiawan, Ade Teti Vani, Budi Yulhasfi Febrianto, Vina Tri Septiana 
design. The sampling method used in this research is stratified random sampling. The sample required in this study is 20 samples.

\section{Procedure}

1. Taking a history and inspection of acne vulgaris by a dermatologist on prospective samples. Samples were obtained according to the inclusion criteria.

2. Grouping the samples according to the degree of acne vulgaris.

3. Giving aloe vera soap and aloe vera gel to the sample for 28 days.

4. Observation on the 29th day

5. Record the degree of acne vulgaris after treatment.

6. Perform data analysis to determine differences in the degree of acne vulgaris before and after treatment.

\section{Data analysis}

The data was obtained from the pre-post test control group design which was processed using SPSS from the data that had been obtained

\section{RESULTS AND DISCUSSION}

Based on The research that has been carried out aims to determine the effectiveness of facial soap and aloe vera gel with the level of acne vulgaris in students at SMA Negeri 2 Bayang with 20 respondents, the authors can describe the results of the research in the exposure below:

\section{Characteristics of respondents}

Age

The results showed that the distribution of the age frequency of students in SMA Negeri 2 Bayang can be described as follows

Table 1. Frequency Distribution of Students' Age at SMA Negeri 2 Bayang

\begin{tabular}{|c|c|c|c|c|c|}
\hline Age & $F$ & $\%$ & Mean & Median & Modus \\
\hline 15 year & 6 & 30 & \multirow{4}{*}{16} & \multirow{4}{*}{16} & \multirow{4}{*}{17} \\
\hline 16 year & 6 & 30 & & & \\
\hline 17 year & 8 & 40 & & & \\
\hline Amount & 20 & 100 & & & \\
\hline
\end{tabular}

Based on table 1, it is found that from 20 respondents, the most students were 17 years old, 8 people (40\%), 15 and 16 years old were the same number of 6 people each (30\%), with a mean of 16 years, a median of 16 years and a mode of action. 17 years.

Gender

The results showed that the distribution of the sex frequencies of students in SMA Negeri 2 Bayang can be described as follows:

Table 2. Gender Frequency Distribution of Students at SMA Negeri 2 Bayang

\begin{tabular}{ccc}
\hline Gender & $\boldsymbol{F}$ & $\boldsymbol{\%}$ \\
\hline Male & 2 & 10 \\
Female & 18 & 90 \\
\hline Amount & 20 & 100 \\
\hline
\end{tabular}

Based on table 2, it was found that from 20 respondents, the most gender were 18 women (90\%) and 2 men (10\%).

Acne pre and post students who are given aloe vera facial and aloe vera gel

The results showed that the frequency distribution of pre and post acne on students who were given aloe vera facial soap and aloe vera gel treatment can be described as follows:

Table 3 Frequency Distribution of Acne Pre and post given Aloe Vera Facial Soap and Aloe

\begin{tabular}{ccc} 
Vera Gel Students at SMA Negeri 2 & Bayang \\
\hline Acne pre A & $\boldsymbol{F}$ & $\mathbf{\%}$ \\
\hline Mild degree & 0 & 0 \\
Moderate Degree & 10 & 100
\end{tabular}

The Effectiveness of Using Aloe Vera Facial Soap and Aloe Gel on the Degree of Acne Vulgaris in Students of SMA Negeri 2 Bayang Putri Bunga Anggreno Setiawan, Ade Teti Vani, Budi Yulhasfi 


\begin{tabular}{ccc} 
Degree of Weight & 0 & 0 \\
\hline Amount & 10 & 100 \\
\hline Acne post A & $\boldsymbol{F}$ & $\boldsymbol{\%}$ \\
\hline Mild Degree & 10 & 100 \\
Moderate Degree & 0 & 0 \\
Degree of Weight & 0 & 0 \\
\hline Amount & 10 & 100 \\
\hline
\end{tabular}

Based on table 3, it was found that out of 10 respondents, acne pre who was given aloe vera facial soap and aloe vera gel were in the moderate degree, namely 10 people $(100 \%)$ and acne post at the mild degree, namely 10 people (100\%).

Acne pre and post students who are given aloe vera facial soap

The results showed that the frequency distribution of pre and post acne in students who were given aloe vera facial soap treatment can be described as follows:

Table 4 Frequency Distribution of Acne Pre and Post Treatment of Aloe Vera Facial Soap by Students at SMA Negeri 2 Bayang

\begin{tabular}{ccc}
\hline Acne pre B & $\boldsymbol{f}$ & $\boldsymbol{\%}$ \\
\hline Mild Degree & 4 & 40 \\
Moderate Degree & 6 & 60 \\
Degree of Weight & 0 & 0 \\
\hline Amount & 10 & 100 \\
\hline & & \\
\hline Acne post B & $\boldsymbol{f}$ & $\boldsymbol{\%}$ \\
\hline Mild Degree & 8 & 80 \\
Moderate Degree & 2 & 20 \\
Degree of Weight & 0 & 0 \\
\hline Amount & 10 & 100 \\
\hline
\end{tabular}

Based on table 4, it was found that out of 10 respondents, the most acne pre treated with aloe vera facial soap were in the moderate degree, namely 6 people $(60 \%)$ and the most acne post was in the mild degree, namely 8 people $(80 \%)$.

Normality Test

The normality test in this study used the Shapiro-Wilk test because the research sample was $<30$ people and the test was carried out on each pre and post data on the treatment given aloe vera facial soap and aloe vera gel with aloe vera facial soap.

Table 5 Normality test

\begin{tabular}{lccl}
\hline Variable & $\begin{array}{c}\text { Signific } \\
\text { ant- } \\
\text { kansi }\end{array}$ & $\begin{array}{c}\text { Signific } \\
\text { ance } \\
\text { Limit }\end{array}$ & Description \\
\hline acne Pre A & 0,363 & 0,05 & Normal \\
$\begin{array}{l}\text { acne Post } \\
\text { A }\end{array}$ & 0,936 & 0,05 & Normal \\
$\begin{array}{l}\text { acne Pre B } \\
\text { acne Post }\end{array}$ & 0,144 & 0,05 & Normal \\
B & & 0,05 & Normal \\
\hline
\end{tabular}

Based on the table above, the results of the Shapiro-Wilk test were obtained in the treatment given aloe vera facial soap and aloe vera gel and aloe vera facial soap before acne obtained a significance value of 0.363 and acne post a significance value of 0.936 . Treatment with aloe vera acne pre facial soap obtained a significance value of 0.144 and acne post a significance value of 0.128 . The

The Effectiveness of Using Aloe Vera Facial Soap and Aloe Gel on the Degree of Acne Vulgaris in Students of SMA Negeri 2 Bayang Putri Bunga Anggreno Setiawan, Ade Teti Vani, Budi Yulhasfi 
results of the significance values of pre and post acne showed a significance value $>0.005$, meaning that the data distribution was normal and for statistical hypothesis testing, the paired sample t-test was used.

\section{Bivariate Analysis}

Analisis bivariat bertujuan untuk mengetahui perbedaan antara acne pre dan post pada perlakuan diberikan sabun wajah aloe vera dan gel aloe vera serta sabun wajah aloe vera menggunakan uji paired sample t-test dan menganalisis perbandingan pemakaian sabun wajah aloe vera dan gel aloe vera dengan sabun wajah aloe vera menggunakan uji independent sample t test.

Table 6. Paired Sample T Test Aloe vera Facial Soap and Aloe Vera Gel with Aloe Vera Facial

\begin{tabular}{|c|c|c|c|c|}
\hline \multirow{3}{*}{ treatment } & \multicolumn{3}{|c|}{ Soap } & \multirow{3}{*}{$\begin{array}{c}\text { Mark } \\
\mathrm{p}\end{array}$} \\
\hline & \multicolumn{2}{|c|}{ IK95\% } & \multirow{2}{*}{$\begin{array}{c}\text { differ } \\
\text { ence }\end{array}$} & \\
\hline & Lower & Upper & & \\
\hline $\begin{array}{l}\text { Vulgaris } \\
\text { Pre }\end{array}$ & \multirow[t]{2}{*}{9.973} & \multirow[t]{2}{*}{19.826} & \multirow[t]{2}{*}{14.9} & \multirow[t]{2}{*}{0,000} \\
\hline $\begin{array}{l}\text { Vulgaris } \\
\text { Post }\end{array}$ & & & & \\
\hline \multirow{2}{*}{$\begin{array}{l}\text { treatmen } \\
\mathrm{t}\end{array}$} & \multicolumn{2}{|c|}{$I K 95 \%$} & \multirow{2}{*}{$\begin{array}{c}\text { diffe } \\
\text { renc } \\
\mathrm{e}\end{array}$} & \multirow[t]{2}{*}{ Mark $p$} \\
\hline & $\begin{array}{c}\text { Lowe } \\
r\end{array}$ & Upper & & \\
\hline $\begin{array}{l}\text { Vulgaris } \\
\text { Pre }\end{array}$ & \multirow[t]{2}{*}{1,494} & \multirow[t]{2}{*}{2,306} & \multirow[t]{2}{*}{1,9} & \multirow[t]{2}{*}{0,000} \\
\hline $\begin{array}{l}\text { Vulgaris } \\
\text { Post }\end{array}$ & & & & \\
\hline
\end{tabular}

Based on the table above, the results of the paired sample t-test showed that the p value of 0.000 was smaller than 0.05 , meaning that there were differences between pre and post use of aloe vera facial soap and the degree of acne vulgaris in students at SMA Negeri 2 Bayang.

Table 7. Independent Sample $T$ Test The treatment was given aloe vera facial soap and aloe vera gel with aloe vera facial soap

\begin{tabular}{lcccc}
\hline \multirow{2}{*}{\begin{tabular}{c} 
Treatmen \\
\cline { 3 - 4 }
\end{tabular}} & \multicolumn{2}{c}{ IK95\% } & differ & Mark p \\
ence & Upper & \\
\hline $\begin{array}{l}\text { Acne } \\
\text { Post A }\end{array}$ & -13.074 & -0.327 & $-6,7$ & 0.040 \\
\cline { 1 - 1 } $\begin{array}{l}\text { Acne } \\
\text { Post B }\end{array}$ & -13.473 & 0.073 & & \\
\hline
\end{tabular}

Based on the table above, the results of the independent sample $t$ test obtained a $p$ value of 0.040 which is smaller than 0.05 , so as the basis for decision making in the independent sample $t$ test, it can be concluded that there is a significant difference between the average results in the treatment given aloe vera facial soap and gel. aloe vera with aloe vera facial soap, the results showed that the use of aloe vera facial soap and aloe vera gel was better for treating acne vulgaris in students of SMA Negeri 2 Bayang than the use of aloe vera facial soap.

\section{DISCUSSION}

\section{Frequency distribution of patients with acne vulgaris based on age in student at SMA Negeri 2 Bayang}

Based on the research, the results obtained from 20 respondents, the age of the most students is 17 years as many as 8 people (40\%), ages 15 and 16 years are the same number of 6 people each (30\%) in SMA Negeri 2 Bayang. This is because the sampling method is taken from each grade 1 to grade 3 at SMA Negeri 2 Bayang so that the age obtained varies by showing that the 15-17 year age range is the age of early adolescence, where at that time teenagers have experienced acne vulgaris.

The Effectiveness of Using Aloe Vera Facial Soap and Aloe Gel on the Degree of Acne Vulgaris in Students of SMA Negeri 2 Bayang Putri Bunga Anggreno Setiawan, Ade Teti Vani, Budi Yulhasfi 
The results of this study are in line with previous research conducted by Sole, (2018) which states that the adolescent age in Manado obtained at the time of the study the most was 17 years, namely (57\%), but different from this previous study conducted by Wibawa, (2019) the results showed that the highest group was in the age range of 15-24 years, namely 39 people $(59.1 \%)$. The difference in this study is due to different samples so that the distribution of age is also different.9, 10

In accordance with the previous theory that acne vulgaris is a chronic inflammation of the pilosebaceous follicles with the highest prevalence at the age of 15-18 years and the age range of 14-17 years is included in the category of early adolescence and starting to enter late adolescence, where about $85 \%$ of adolescents have experienced acne vulgaris. .

\section{Distribution Frequency of Acne vulgaris Patients Based on Gender in Students of SMA Negeri 2 Bayang}

Based on the research, the results obtained from 20 respondents, the most gender were 18 women (90\%) and 2 men (10\%) in SMA Negeri 2 Bayang. This shows that women experience acne vulgaris more than men.

The results of this study are in line with previous research conducted by Sibero, (2019) found that acne vulgaris was more experienced by women (69.7\%) than men (30.3\%)12 and also Wibawa's research (2019) found that the number of 19 male patients with acne vulgaris (28.8\%) and 47 female patients $(71.2 \%) .9$

This is because women pay more attention to their appearance besides that according to the peak severity of acne vulgaris occurs earlier in women compared to men, so it is more encouraging for women to go to the doctor. The trigger factors for acne vulgaris in women are hormonal and cosmetic factors. Hormones can affect the severity of acne vulgaris in women, the hormones estrogen and progesterone play an important role in the mechanism of acne vulgaris because they are influenced by the menstrual cycle, in women acne vulgaris will appear more days before the menstrual cycle and will persist for more than a week after menstruation, during puberty, hormones rise. Androgens play an important role in the blood and can cause hyperplasia and hypertrophy of the sebaceous glands so that acne vulgaris is most common in adolescents. 13 Cosmetics can cause closed comedones with some papulopustular lesions on the cheeks and chin, because the ingredients contained in cosmetics are comedogenic. resulting in increased sebum production. Comedogenic ingredients such as lanolin, petrolatum, essential oils, butyl stearate, lauryl alcohol and oleic acid. These ingredients are found in various face creams such as foundation, moisturizer, sun protection cream which causes acne vulgaris.

\section{Frequency Distribution of Acne vulgaris Pre and Post Giving Face Soap and Aloe Vera} Gel to Students at SMA Negeri 2 Bayang.

Based on the research, the results obtained from 10 respondents, acne vulgaris pre given the treatment of aloe vera facial soap and aloe vera gel were in the moderate degree, namely 10 people (100\%) and post at the mild degree, namely 10 people (100\%) at SMA Negeri 2 Bayang. This shows that after being given the treatment, namely the provision of aloe vera facial soap and aloe vera gel, the degree of acne vulgaris decreased from moderate to mild. The results of this study are in line with Putra's research, (2020) obtained the highest degree of moderate acne vulgaris as many as 176 people $(65.2 \%) 15$ but it is different from previous research conducted by Gomarjoyo, (2019) in students of SMKN 1 Samarinda obtained the degree of acne vulgaris most students are mild (93.2\%).16

The number of respondents experienced moderate acne vulgaris before being given aloe vera soap and gel, this was caused by many factors such as the use of cosmetics, especially in women. The cause of acne vulgaris is the oil element excess in cosmetic products. Oil will act like oil natural and can clog pores and the presence of dyes can aggravate acne. Acne is more commonly found in the chin and cheek areas, compared to the forehead area, initially in the form of small bumps and lesions that look reddish. Cosmetic acne scars less often, but can persist for years as a result of continuous use of cosmetics. 17

Acne vulgaris is a disease that occurs due to inflammation of the skin polysebaceous follicles that play a role in producing sebum and often occurs in adolescence. Clinical features that refer to acne

The Effectiveness of Using Aloe Vera Facial Soap and Aloe Gel on the Degree of Acne Vulgaris in Students of SMA Negeri 2 Bayang Putri Bunga Anggreno Setiawan, Ade Teti Vani, Budi Yulhasfi 
vulgaris include excessive oil production, non-inflammatory lesions such as open comedones and closed comedones, and inflammatory lesions such as papules and pustules.

The decrease in the degree of acne vulgaris after being given treatment with aloe vera facial soap and aloe vera gel, it proves that aloe vera facial soap and aloe vera gel can reduce the degree of acne vulgaris. Aloe vera gel is proven to be effective in killing and inhibiting the growth of bacteria that cause acne vulgaris. Aloe vera contains active substances such as saponins, tannins, and phenols. Saponins are alkaloids that can damage bacteria (DNA and RNA), while saponins dissolve lipids in bacterial cell membranes so that bacterial cell functions become abnormal and lysis. Tannins are antibacterials that work by inactivating adhesins so that bacteria cannot attach to host epithelial cells. Tannins also have antioxidant activity inhibiting tumor growth and enzymes, tannins also have antiseptic properties that can prevent damage caused by bacteria.

\section{Frequency Distribution of Degress of Acne vulgaris Pre and Post Giving Aloe Vera Facial Soap to Students at AMA Negeri 2 Bayang}

Based on the research, the results were obtained from 10 respondents, the most acne pre given aloe vera facial soap was in the moderate degree, namely 6 people (60\%) and the most acne post was in the mild degree, namely 8 people (80\%) at SMA Negeri 2 Bayang. This shows that after being given treatment, namely giving aloe vera facial soap, the degree of acne vulgaris decreased from moderate to mild, but there were still 2 people in the moderate category. This study is in line with Marliana, (2018) which states that the ingredients contained in face wash have the ability to inhibit the growth of Propionibacterium acnes bacteria that causes acne vulgaris.19 According to Tarek, (2021) aloe vera has proven its effectiveness in killing and inhibiting the growth of bacteria that cause acne. vulgaris. Aloe vera can also be used as an antiseptic and antibiotic. This aloe vera produces 6 antiseptic agents such as lupeol, salicylic acid, urea nitrogen, cinnamonic acid, phenol and sulfur. All of these substances are classified as antiseptics because they can kill germs or control the formation of bacteria.Knowing the effectiveness of using aloe vera facial soap and aloe vera gel with aloe vera facial soap against the degree of acne vulgaris in students of SMA Negeri 2 Bayang Based on the table above, the results of the independent sample $t$ test obtained that the $p$ value of 0.040 is smaller than 0.05 , so as the basis for decision making in the independent sample $t$ test, it can be concluded that there is a significant difference between the average results of aloe vera facial soap and aloe vera gel with soap. aloe vera face, the results showed that the use of aloe vera facial soap and aloe vera gel was better for treating acne vulgaris in students of SMA Negeri 2 Bayang than the use of aloe vera facial soap.

Proving the effectiveness of aloe vera has previously been carried out by many studies, such as the Silpi study, (2017) on the Effects of aloe vera gel on acne vulgaris. Pre and post treatment, the results showed that there was a significant difference in the mean before and after being given aloe vera gel to medical students class 2019 Faculty of Medicine. Baiturrahmah.20

The effect of using aloe vera soap and aloe vera gel can treat acne vulgaris because aloe vera contains ingredients that are useful in reducing the degree of acne vulgaris, but the use of facial soap that is rinsed directly causes the duration of the product content that serves to reduce the degree of acne vulgaris shorter so that it penetrates into the skin. skin layer is not optimal. Giving aloe vera gel is better because aloe vera gel contains the content of reducing the degree of acne vulgaris by applying aloe vera gel to the facial skin for a long duration and can penetrate the skin layers so that the beneficial ingredients can work effectively. Aloe vera gel includes several compounds such as vitamin $\mathrm{E}$ and vitamin $\mathrm{C}$ and several amino acids, which can play an important role in accelerating wound healing to such an extent that experiments have shown that vitamin $\mathrm{C}$ can play a role in increasing collagen production and preventing the synthesis of DNA strands, as well as vitamin E. as a powerful antioxidant in wound healing. Aloe vera gel has an enzymatic system of antioxidants such as glutathione peroxidase and superoxide dismutase, which accelerate wound healing by neutralizing the effects of free radicals generated at the wound site and with anti-inflammatory properties.

Prevention of acne vulgaris can be overcome by maintaining facial skin cleanliness, cleaning facial skin regularly by washing your face twice a day can remove dirt, dust, oil which will reduce skin fat and prevent bacteria from entering the polysebaceous ducts and remove dead skin on the surface of the

The Effectiveness of Using Aloe Vera Facial Soap and Aloe Gel on the Degree of Acne Vulgaris in Students of SMA Negeri 2 Bayang Putri Bunga Anggreno Setiawan, Ade Teti Vani, Budi Yulhasfi Febrianto, Vina Tri Septiana 
face. , reduce blackheads, and can reduce inflammation so as to minimize the possibility of acne vulgaris. 23 The ingredients contained in facial washing soap can inhibit the growth of bacteria that cause acne vulgaris, such as benzoyl peroxide which works by forming free radicals that can inhibit bacterial metabolism, so soap can prevent the growth of bacteria that cause acne vulgaris. Sodium sulfacetamide has the ability to inhibit the growth of Propionibacterium acnes. Sulfur inhibits the growth of Propionibacterium acnes and plays a role in keratinolysis, thereby closing the skin pores and reducing the production of sebaceous glands.

\section{CONCLUSION}

Based on the results of research on the effectiveness of using aloe vera facial soap and aloe vera gel on the degree of acne vulgaris in SMA Negeri 2 Bayang students, it can be concluded that giving aloe vera facial soap and aloe vera gel provides a better improvement on the degree of acne vulgaris than giving facial soap. aloe vera in adolescent acne vulgaris patients.

\section{REFERENCES}

[1] Saragih df, opod h, pali c. Hubungan tingkat kepercayaan diri dan jerawat (acne vulgaris) pada siswa-siswi kelas xii di sma negeri 1 manado. J e-biomedik. 2016;4(1):0-7.

[2] Sihaloho k, indramaya dm. Hubungan antara diet dan akne (relationship between diet and acne). Period dermatology venereol. 2016;28(2):77-82.

[3] Rahmanisa s, oktaria r. Pengaruh epigallocatechin-3-gallate ( egcg ) pada teh hijau terhadap acne vulgaris the effect of epigallocatechin-3-gallate ( egcg) in green tea to acne vulgaris. 2016;5(april):101-5.

[4] Ariyani sb, hidayati h. Penambahan gel lidah buaya sebagai antibakteri pada sabun mandi cair berbahan dasar minyak kelapa. J ind has perkeb. 2018;13(1):11-8.

[5] Yuniarsih n, akbar f, lenterani i, farhamzah. Formulasi dan evaluasi sifat fisik facial wash gel ekstrak kulit buah nagaa merah (hylocereus polyrhizus) dengan gelling agent carbopol. Pharma xplore j ilm farm. 2020;5(2):57-67.

[6] Prima ms. Hubungan kebersihan kulit wajah dengan timbulnya akne vulgaris pada siswa tata kecantikan di kota padang. J pendidik dan kel. 2018;10(2):167.

[7] Bahar m, yusmaini h. Efek antimikroba ekstrak lidah buaya (aloe vera) terhadap isolat bakteri penyebab acne vulgaris secara invitro. J profesi med j kedokt dan kesehat. 2018;11(2).

[8] Afriyanti rn. Akne vulgaris pada remaja. Med fac lampung univ. 2015;4(6):102-9.

[9] Wibawa igae, winaya kk. Karakteristik penderita acne vulgaris di rumah sakit umum (rsu) indera denpasar periode 2014-2015. J med udayana [internet]. 2019;8(11):1-4. Available from: Https://ojs.unud.ac.id

[10] Sole frt, suling pl, kairupan ts. Hubungan antara mencuci wajah dengan kejadian akne vulgaris pada remaja laki-laki di manado. E-clinic. 2019;8(1):158-62.

[11] Mauliza Mila, Elmiyati, Andri. Pengaruh penggunaan kosmetik terhadap acne vulgaris pada remaja putri kelas I dan kelas II SMA Negeri 4 Banda Aceh. Jurnal ilmu kedokteran dan kesehatan, volume 7, nomor 1, Januari 2020

[12] Sibero ht, sirajudin a, anggraini di, dokter $\mathrm{p}$, kedokteran $\mathrm{f}$, lampung $\mathrm{u}$, et al. Prevalensi dan gambaran epidemiologi akne vulgaris di provinsi lampung the prevalence and epidemiology of acne vulgaris in lampung. Jk unila. 2019;3(2):308-12.

[13] Ulfah Nandaria. Hubungan paparan kosmetik dengan kejadian akne vulgaris pada mahasiswi fakultas kedokteran. Jurnal health sains, vol. 1 no. 6, Desember 2020

[14] Mutiara, stephanie. Pengaruh penggunaan kosmetik skin care terhadap timbulnya acne vulgaris pada siswa kecantikan SMKN 6 dan SMKN 7 Padang. Jurnal pendidikan dan keluarga 2019

[15] Putra a. Profil penderita acne vulgaris yang mendapatkan terapi antibiotik oral dan topikal di balai kesehatan kulit, kelamin dan kosmetika makassar periode 2018-2019. Universitas hasanuddin makassar. 2020

The Effectiveness of Using Aloe Vera Facial Soap and Aloe Gel on the Degree of Acne Vulgaris in Students of SMA Negeri 2 Bayang Putri Bunga Anggreno Setiawan, Ade Teti Vani, Budi Yulhasfi 
[16] Gomarjoyo f, kartini a, nuryanto mk. Hubungan jenis kelamin, indeks massa tubuh dan perawatan wajah dengan derajat keparahan acne vulgaris. J kebidanan mutiara mahakam. 2019;7(1):31-40.

[17] Gomarjoyo Fanny, Kartini Agnes, Nuryanto M Khairul. Hubungan jenis kelamin, indeks massa tubuh dan perawatan wajah dengan derajat keparahan acne vulgaris. Jurnal kebidanan mutiara mahakam, vol 7, nomor 1, 2019

[18] Ahmed Mohammed Ali, Tarek. Literature riview evaluasi sedian ekstrak daun lidah buaya (aloe vera (L.)webb) sebagai anti jerawat pada uji pra klinis dan uji klinis. Fakultas kedokteran dan ilmu kesehatan, universitas islam negeri muhammad malik ibrahim. Malang : Universitas Islam Negeri Muhammad Malik Ibrahim; 2021.

[19] Marliana. Efektivitas beberapa produk pembersih wajah antiacne terhadap bakteri penyebab jerawat Propionibacterium acnes. 2018;5(1): Hal. 31-41.

[20] Silpi m. Efek gel aloe vera terhadap akne vulgaris pada mahasiswa kedokteran angkatan 2019 fakultas kedokteran universitas baiturrahmah. Skripsi. 2019;4(3):57-71.

[21] Sinaga Fiona. Gambaran pemakaian kosmetik pada pasien akne vulgaris di poliklinik kulit dan kelamin RSU Royal Prima dan Murni Teguh Memorial Hospital kota Medan. 2020.

[22] Rienda Monica Novyana, Susanti. Aloe vera untuk penyembuhan luka. 2016

[23] Retno Try Lestari, Lailatul Zakiyah Gifanda,Erika Laila Kurniasari,Ragilia Puspita Harwiningrum. Perilaku mahasiswa terkait cara mengatasi jerawat. Jurnal farmasi komunitas 8 (1), 15-19, 2021

The Effectiveness of Using Aloe Vera Facial Soap and Aloe Gel on the Degree of Acne Vulgaris in Students of SMA Negeri 2 Bayang Putri Bunga Anggreno Setiawan, Ade Teti Vani, Budi Yulhasfi 